\title{
Introduction to the absolute chronology of Neolithic cultures in Eastern Europe
}

\author{
Andrey Mazurkevich \\ The State Hermitage Museum, Department of Archaeology of Eastern Europe and Siberia, Sankt-Peterburg, RU \\ a-mazurkevich@mail.ru
}

\begin{abstract}
This paper is an introduction to the discussion of radiocarbon chronology of Neolithic cultures in Eastern Europe. It relates to a number of papers published in this volume.
\end{abstract}

KEY WORDS - Neolithic cultures; radiocarbon chronology; Eastern Europe

\author{
Uvod k absolutni kronologiji \\ neolitskih kultur na območju Vzhodne Evrope
}

IZVLEČEK - Članek je uvod v diskusijo o radiokarbonski kronologiji neolitskih kultur v vzhodni Evropi. Nanaša se na tekste, objavljene v tej publikaciji.

KLJUČNE BESEDE - neolitske kulture; radiokarbonska kronologija; vzhodna Evropa

Discussions about radiocarbon dates and the origin of dated materials have led to a revision of the absolute chronology of Neolithic cultures in Eastern Europe (Mazurkevich et al. 2016). On the other hand, it has been suggested that a series of radiocarbon dates should be rejected due to the questionable nature of the dated material, i.e. organic material from pottery, food crust etc. (cf. van der Plicht et al. 2016). Source criticism as a 'form of cognition' deepens our understanding of facts. However, we appear to be too critical, often forgetting about archaeological/historical possibilities for verifying dates and interpretation of a surprisingly old/ young 'absolute' radiocarbon date.

Radiocarbon dates are not just dry figures; they conceal complex physical processes which reflect the natural history of the Earth. The accuracy and validity of radiocarbon dates have become two of the most important subjects recently. The results obtained while dating different materials from archaeological sites are regarded in light of the development of radiocarbon dating methods, the validity of the result obtained (taking into account, for example, the reservoir effect) and the possibility of its use in further reconstructions of historical background.

Discussions about the reservoir effect have a particular importance for the radiocarbon chronology of Eastern Europe, given the complex foraging economy of the ancient inhabitants of this region, where fishing often played a major role. Research of the reservoir effect in Denmark and Northern Germany has shown different values for the reservoir effect for different epochs and regions (Philippsen, Heinemeier 2013; Philippsen 2013). The dating of modern samples indicates that the freshwater reservoir effect is great and also variable even on short time scales. It has been suggested that it is impossible to find a single freshwater reservoir age for a given river system (Philippsen 2013). Recent research testifies to the difficulties in determining the reservoir effect, which might influence dates, as well as offset values. The detection of aquatic (fish) processing in charred food residue even by the use of the stable isotopes $13 \mathrm{C}$ and $15 \mathrm{~N}$ (Boudin et al. 2010) may be complicated, or an unlikely prospect. 
Investigations into the reservoir effect and arrays of radiocarbon dates related to Neolithic materials from Eastern Europe illustrate different possible scenarios (see, for example, articles by Piezonka et al. and Dolbunova et al. in this volume). Studies of sites in the Dnepr-Dvina region indicate differences in offset values even for different micro-regions and for different epochs. The comparative ${ }^{14} \mathrm{C}$ dating of wooden piles, food-crusts, fish and animal bones at the Serteya II site show that the FRE in Late Neolithic pottery food-crusts is generally negligible for this area (Kulkova et al. 2015; 2016). The reservoir effect may also be absent in some of the regions ( $c f$. Marchenko et al. 2015).

Another problem is related to the calibration of dates and the existence of plateaus. The appearance of the most ancient pottery in Eastern Europe is dated to the first half of the $7^{\text {th }}$ millennium $\mathrm{BC}$, a period with one such plateau, which does not allow a more accurate chronology of this process (Mazurkevich et al. 2016).

The choice of dating material is another important problem. It relates to the reliability of the archaeological context and, hence, the contemporaneity of different events represented by different materials. Events might have overlapped at an archaeological site which was occupied repeatedly. In cases when all artefacts, faunal remains and other objects were not recorded in a 3-D coordinate system, it might be difficult to divide these events, and their contemporaneity may appear to be doubtful. On the other hand, the choice of material for dating sites in Eastern Europe is determined mainly by the absence of a wide range of organic materials (wood, food crust, charcoal), which led to the use of pottery as a popular material for radiocarbon dating. The reliability of this material has been much discussed, although the first attempts to date organic material from pottery were made already at the end of the 1950s (de Atley 1980.988). The main problem is that carbon from non-cultural sources may also be present in ceramic materials, and this may effectively dilute the age or otherwise contaminate the cultural sample and, thus, different sources of carbon are possible (de Atley 1980; Bonsall et al. 2002; Zaitseva et al. 2009).

At first, many dates of pottery for the territory of Eastern Europe were primarily made in the Kyiv radiocarbon laboratory, which allowed a proposed scheme of absolute chronology for regions from where almost no radiocarbon dates had been obtained before (Vybornov 2008). These dates and the method itself were highly criticised ( $c f$. van der Plicht et al. 2016). The number of dates for organic material on pottery from different laboratories as well as cross-dating of other materials has now increased dramatically (see article of Vybornov et al. in this volume; Mazurkevich et al. 2016). The coincidence of the series of dates obtained in different laboratories by different methods (AMS and conventional dates) and on different materials requires a specific discussion by specialists in this domain. A comparison and coincidence of different dates does not allow us to avoid this discussion or to neglect dates of organic material on pottery (see article of Vybornov et al. in this volume).

The radiocarbon chronology of Eastern Europe is based mainly on conventional dates, which extend the periods of the earliest ceramic cultures attributed to Neolithic era according to Russian scientific tradition. The correlation of processes dated by conventional dates and more precise AMS dates will allow us to narrow the period covering the appearance and longevity of these traditions.

During the last two decades, radiocarbon dates became the main resource for constructing different chronological and historical-cultural models. These important issues side-lined archaeological proxies, which led to the creation of various mathematical models, with very little consideration of archaeological context (cf. Davison et al. 2009; Silva et al. 2014; Jordan et al. 2016). All these models were based on the values of radiocarbon dates and were not corrected with data about archaeological context, the typology of materials, cultural entities or cultural networks identified on the basis of archaeological materials. Thus a reverse trend can be noticed: all 'historical/cultural' connections and processes are adjusted to a certain mathematical (chronological) model.

The reliability of ${ }^{14} \mathrm{C}$ dates can be also verified by correlating these dates with typologies which were constructed on the basis of other independent proxies/principles or methods. This is well illustrated by the various discussions about the chronology of Rakushechny Yar, one of the oldest Neolithic sites in Eastern Europe, dated to the $7^{\text {th }}-6^{\text {th }}$ millennium cal BC. New investigations, including analysis of the context of dated materials, archive research and archaeological excavations allowed the chronology of this site to be refined and a revision of the notion that the existing chronology of southern Russia is unreliable (see Tsybrij et al. in this volume). 
The radiocarbon dates collected for different periods of the Neolithic challenged our habitual linear scheme, the perception of continuity within the development of the Neolithic period. We can trace the asynchrony of various cultural events in different regions, as opposed to gradual changes in cultures (see Mazurkevich et al. in this volume). Radiocarbon dates challenge our notions about chronological boundaries between different cultures, as well as epochs. They require us to think more about the possibility that societies with different cultural attributions in different epochs coexisted. It is especially clearly seen on maps showing site distribution according to their chronology (Maps 1-5). Could such a 'striped pattern' have existed in the past? Our interpretation is also greatly influenced by stereotypes about primitive societies, which intentionally opted for such a way of life and preserved society in such a state (Artemova 2009). Interpretation is also influenced by our perception of time, when several hundreds of years or one millennium are regarded as a short period, and not as the lifetime of at least forty generations.

New radiocarbon dates will allow us to refine the chronology of different processes and influence much of our interpretation of social changes in the Neolithic era. It is important also to regard arrays of data grouped according to the main river basins of Eastern Europe, which served as waterways in the past, along which major migrations could have occurred.
The tradition of compiling radiocarbon dates has a long history. In Russian historiography, such compilations have been made since the 1970s; Pavel M. Dolukhanov, Vladimir I. Timofeev and Aleksandr M. Miklyaev laid the basis for this tradition (cf. Dolukhanov et al. 1969; 1972; 1978; Timofeev et al. 1978; 2004; Mazurkevich et al. 2014). Such data compilation will continue to be published when a 'critical amount' of dates become available, giving rise to new discussions. The articles represented are devoted to different aspects of radiocarbon dating and chronology of Neolithic materials in Eastern Europe from the $7^{\text {th }}$ to the $3^{\text {rd }}$ millennium BC. The territory of research presented in this volume encompasses almost the whole of Eastern Europe, from the Lower Don River and Eastern Ukraine to Finland, from the Dnepr River basin to the Urals. The data and maps presented in the monographs reveals one more problem, about the definition of the Neolithic, the Neolithic revolution, and the Early, Middle and Late Neolithic, their chronological boundaries, which appear to be transparent in many cases, and how they can be distinguished one from another on the basis of archaeological features. The articles devoted to Eastern European chronology presented in this volume do not encompass all known radiocarbon dates for this area, but suggest another, new, point of view of the Neolithic in Eastern Europe.

\section{References}

Artemova 0. Yu. 2009. Koleno Isava. Ohotniki, sobirateli, rybolovy. Opyt izucheniya al'ternativnyh social'nyh sistem. Smysl. Moskva. (in Russian)

de Atley S. P. 1980. Radiocarbon dating of ceramic materials: Progress and prospects. Radiocarbon 22(3): 987993.

Bonsall C., Cook G., Manson J. L. and Sanderson D. 2002. Direct dating of Neolithic pottery: progress and prospects. Documenta Praehistorica 29: 47-59.

Boudin M., Van Strydonck M., Crombé P., De Clercq W., van Dierendonck R. M., Jongepier H., Ervynck A. and Lentacker A. 2010. Fish reservoir effect on charred food residue ${ }^{14} \mathrm{C}$ dates: are stable isotope analyses the solution? Radiocarbon 52(2): 697-705.
Davison K., Dolukhanov P. M., Sarson G. R., Shukurov A. and Zaitseva G. I. 2009. Multiple Sources of the European Neolithic: Mathematical Modelling Constrained by Radiocarbon Dates. Quaternary International 203: 10-18.

Dolbunova E., Kostyleva E., Kulkova M., Meadows J., Mazurkevich A. and Lozovskaya 0. 2017. Chronology of Early Neolithic materials of the site Sakhtysh IIa (Central Russia). Documenta Praehistorica 44: 176-191.

Dolukhanov P. M., Semencov A. A. and Romanova E. N. 1969. Radiouglerodnye daty laboratorii LOIA. Sovetskaya arheologiya 1: 251-261. (in Russian)

1972. Radiouglerodnye daty laboratorii LOIA (19681969). Sovetskaya arheologiya 3: 209-218. (in Russian) 
Dolukhanov P. M., Liiva A. A. and Miklyaev A. M. 1978. Problemy absolyutnoi hronologii kul'tur V-II tysyacheletii do n. e. v basseine Baltiiskogo morya. Pamyatniki epohi neolita. Kratkie soobschenia instituta arheologii 153: 25-30. (in Russian)

Jordan P., Gibbs K., Hommel P., Piezonka H., Silva F. and Steele J. 2016. Modelling the diffusion of pottery technologies across Afro-Eurasia: emerging insights and future research. Antiquity 90(351): 590-603.

Kulkova M., Mazurkevich A., Dolbunova E., Regert M., Mazuy A., Nesterov E. and Sinai M. 2015. Late Neolithic subsistence strategy and reservoir effects in ${ }^{14} \mathrm{C}$ dating of artifacts at the pile-dwelling site Serteya II (NW Russia). $R a$ diocarbon 57(4): 611-623.

Kulkova M. A., Sinai M. Yu., Mazurkevich A. N., Dolbunova E. V. and Nesterov E. M. 2016. 'Reservoir effect' estimation basing on the analysis of 'hard water effect' in Usviatsky and Serteysky microregion of Dnepr-Dvina region. In A. N. Mazurkevich, M. A. Kulkova and E. Dolbunova (eds.), Radiouglerodnaya hronologiya epohi neolita Vostochnoi Evropy $v$ VII-III tys. do n.e. Gosudarstveniy Ermitaz, Rosiskaya akademiya nauk, Institut materialnoy kulturi, Samarskiy gasudarstveniy socialno-pedagogicheskiy universitet. Svitok. Smolensk: 38-47. (in Russian)

Marchenko Z., Orlova L. A., Panov V. S., Zubova A. V., Molodin V. I., Pozdnyakova O. A., Grishin A. E. and Uslamin E. A. 2015. Paleodiet, radiocarbon chronology, and the possibility of fresh-water reservoir effect for Preobrazhenka 6 burial ground, Western Siberia: preliminary results. Radiocarbon 57(4): 595-610.

Mazurkevich A. N., Polkovnikova M. E. and Dolbunova E. V. (eds.) 2014. Arheologiya ozernyh poselenii IV-II tys. do n.e.: Hronologiya kul'tur i prirodno-klimaticheskie ritmy Periferiya. Sankt-Peterburg. (in Russian)

Mazurkevich A. N., Kulkova M. A. and Dolbunova E. (eds.) 2016. Radiouglerodnaya hronologiya epohi neolita Vostochnoi Evropy $v$ VII-III tys. do n.e. Gosudarstveniy Ermitaz, Rosiskaya akademiya nauk. Institut materialnoy kulturi, Samarskiy gasudarstveniy socialno-pedagogicheskiy universitet. Svitok. Smolensk. (in Russian)

Mazurkevich, A. N., Dolbunova E. V., Zaitseva G. I. and Kulkova M. A. 2017. Chronological timeframes of cultural changes in Dnepr-Dvina region ( $7^{\text {th }}$ to $3^{\text {rd }}$ millennium BC). Documenta Praehistorica 44: 162-175.
Philippsen B. 2013.The freshwater reservoire effect in radiocarbon dating. Heritage Science 1: 24.

Philippsen B., Heinemeier J. 2013. Freshwater reservoir effect variability in Northern Germany. Radiocarbon 55 (2-3): 1085-1101.

Piezonka H., Nedomolkina N., Ivanishcheva M., Kosorukova N., Kul'kova M. and Meadows J. 2017. The Early and Middle Neolithic in NW Russia: Radiocarbon chronologies from the Sukhona and Onega regions. Documenta Praehistorica 44: 122-151.

Silva F., Steele J., Gibbs K. and Jordan P. 2014. Modeling spatial innovation diffusion from radiocarbon dates and regression residuals: The case of early old world pottery. Radiocarbon 56(2): 723-732.

Van der Plicht J., Shishlina N. I. and Zazovskaya E. P. 2016. Radiouglerodnoe datirovanie: hronologiya arheologicheskih kul'tur i rezervuarnyi effekt. Paleograf. Moskva. (in Russian)

Timofeev V. I., Romanova E. N., Malanova N. S. and Svezhencev Yu. S. 1978. Radiouglerodnye datirovki neoliticheskih pamyatnikov SSSR. Pamyatniki epohi neolita. Kratkie soobschenia Instituta archeologii 153: 14-18. (in Russian)

Timofeev V. I., Zaitseva G. I., Dolukhanov P. M. and Shukurov A. M. 2004. Radiouglerodnaya khronologija neolita Severnoi Evrazii. Teza. St. Petersburg. (in Russian)

Tsybrij A., Tsybrij V., Dolbunova E., Mazurkevich A., Kulkova M. and Zaitseva G. 2017. Radiocarbon chronology of Neolithic in the Low Don and North-eastern Azov Sea. Documenta Praehistorica 44: 204-222.

Vybornov A. A. 2008. Neolit Volgo-Kam'ya. Izdatelstvo Samarskogo gosudarstvennogo pedagogicheskogo universiteta. Samara. (in Russian)

Vybornov A., Kulkova M., Andreev K. and Nesterov E. 2017. Radiocarbon chronology of the Neolithic in the Povolzhye (Eastern Europe of Russia). Documenta Praehistorica 44: 224-239.

Zaitseva G., Skripkin V., Kovalyukh N., Possnert G., Dolukhanov P. and Vybornov A. 2009. Radiocarbon dating of Neolithic pottery. Radiocarbon 51(2): 795-801. 


\section{List of sites shown on Maps 1-5}

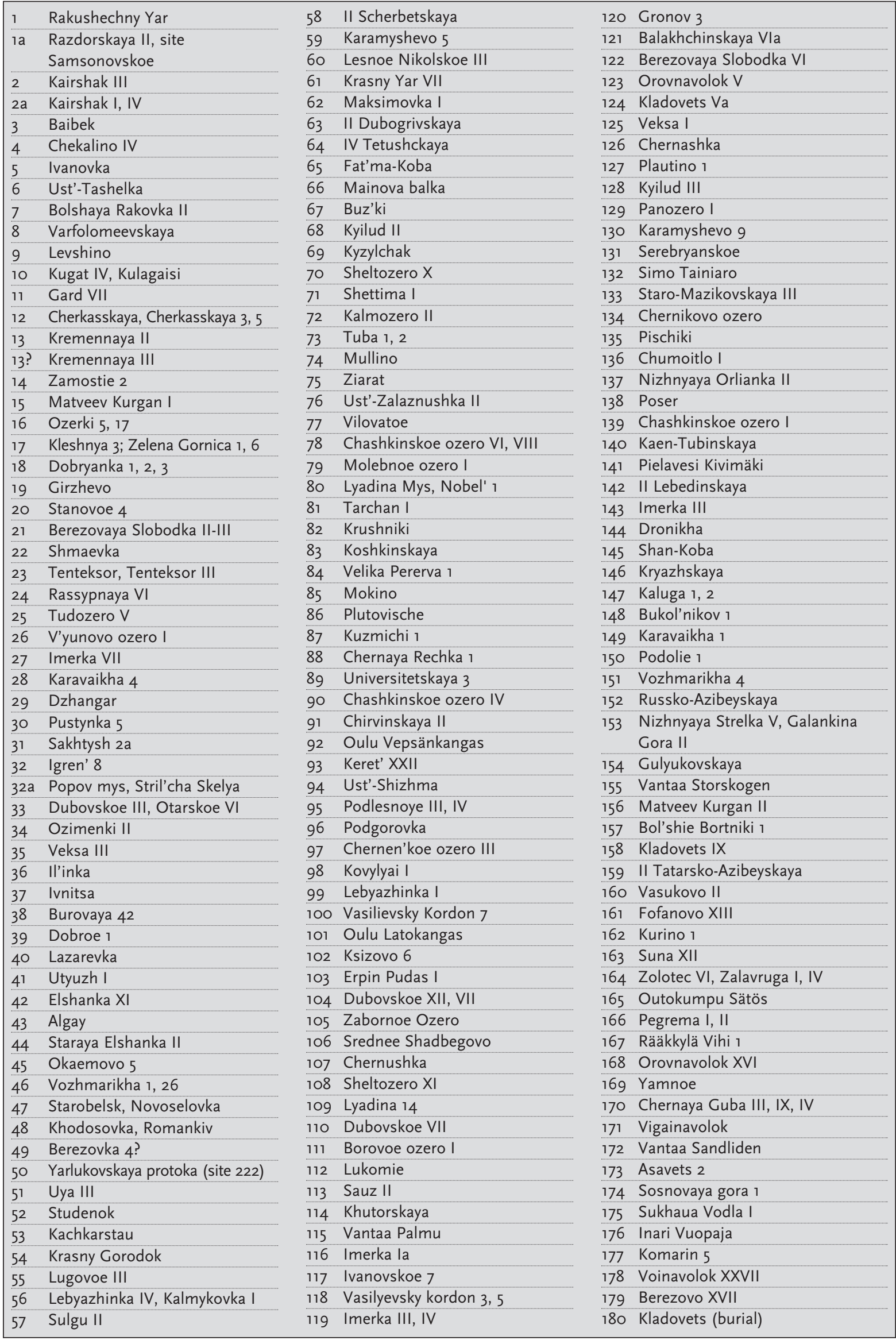




\begin{tabular}{|c|c|c|c|c|c|}
\hline 181 & Prorva 2 & 191 & Chernaya Rechka XII & 202 & Serteya XXIV \\
\hline 182 & Pin'guba II & 192 & Lakshezero II, Kudoma X & 203 & Serteya XXIV \\
\hline 183 & Tunguda III, XIV, XVII & 193 & Kostomuksha II & 204 & Serteya VIII \\
\hline 184 & Meieri II & 194 & Vigainavolok II & 205 & Serteya XXXVI \\
\hline \multirow[t]{2}{*}{185} & Povenchanka XV, Voinavolok & 195 & Palaiguba II & 206 & Serteya I, II \\
\hline & XXIV, Kochnavolok II & 196 & Zhekolgan & 207 & Serteya XI \\
\hline 186 & Nizhnyaya Olba 1 & 197 & Sutyrskaya V & 208 & koorgan near village Serteya \\
\hline 187 & Orovnavolok XI & 198 & Serteya XIV & 209 & Dubokray V \\
\hline 188 & Kudomguba VII & 199 & Rudnya Serteyskaya & 210 & Dubokray IX, I \\
\hline 189 & Zolotec IX, X, XX & 200 & Serteya $X$ & 211 & Usviaty IV \\
\hline & Chelmuzhskaya kosa XXI & 201 & Serteya XXVII, XXII & 212 & Naumovo \\
\hline
\end{tabular}

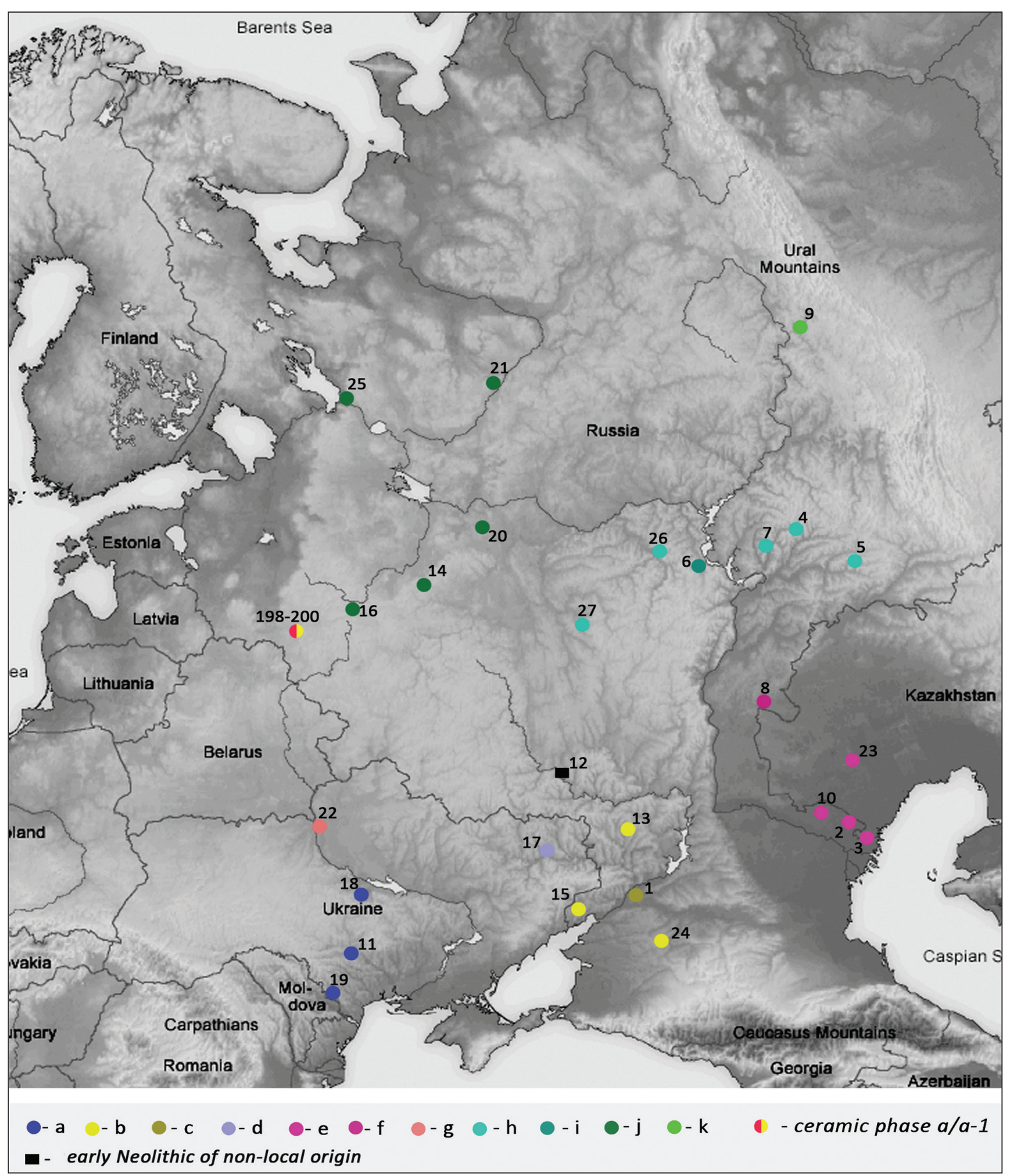

Map 1. Sites of the $7^{\text {th }}$ millennium BC based on radiocarbon dating (modified from Mazurkevich et al. 2016). 


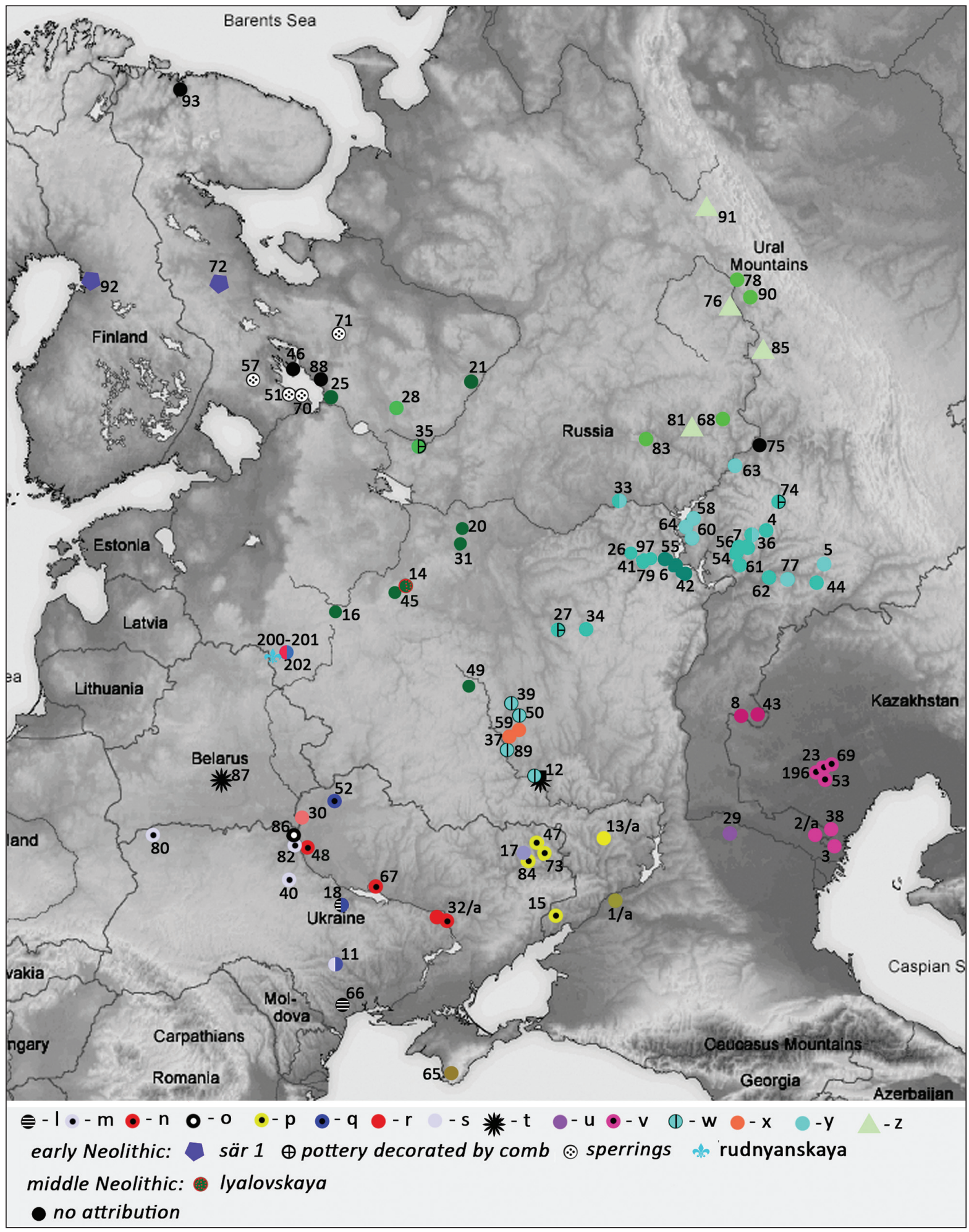

Map 2. Sites in the turn of the $7^{\text {th }}$ to $6^{\text {th }}$ millennium BC. 


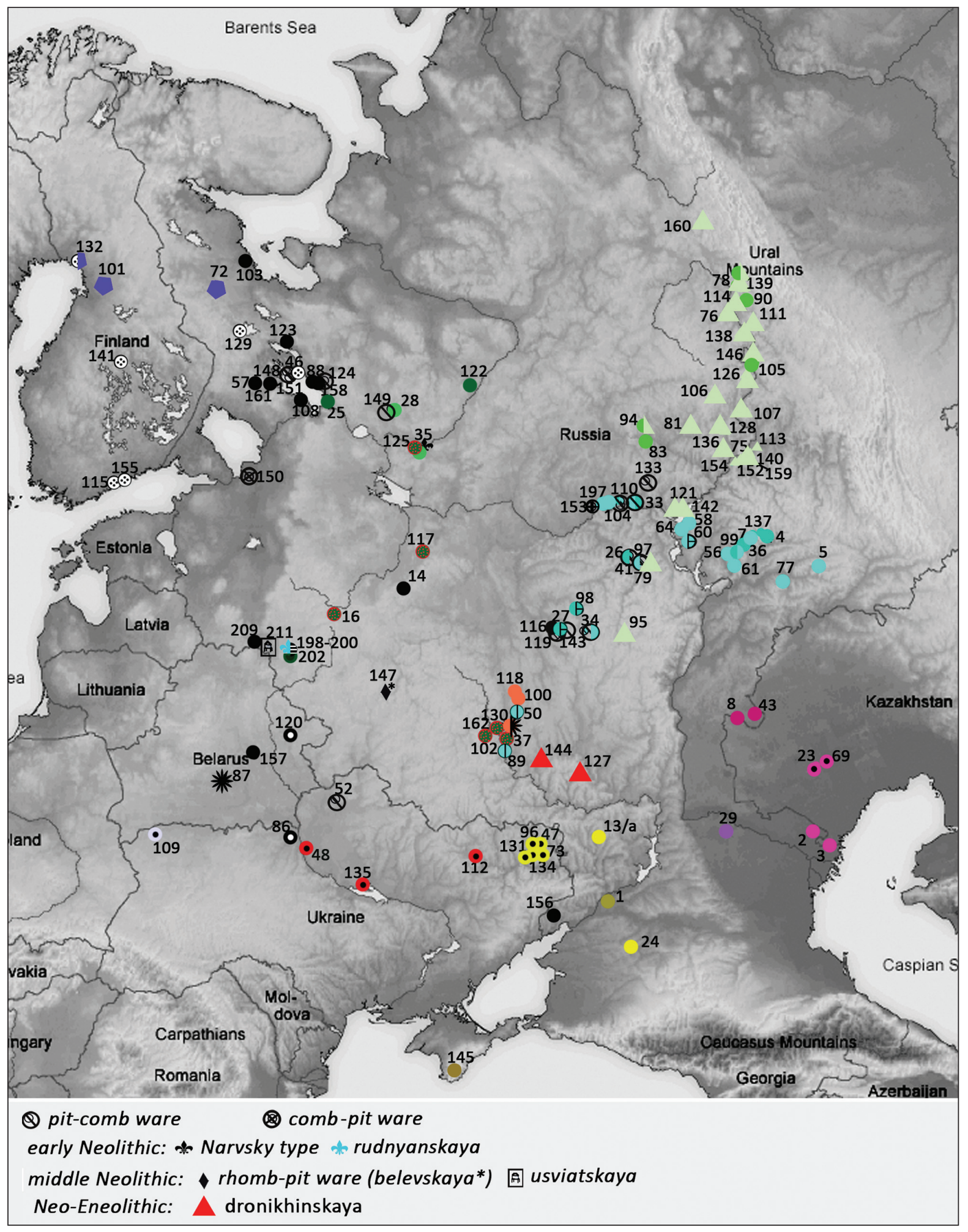

Map 3. Sites in the turn of the $6^{\text {th }}$ to $5^{\text {th }}$ millennium $B C$. 


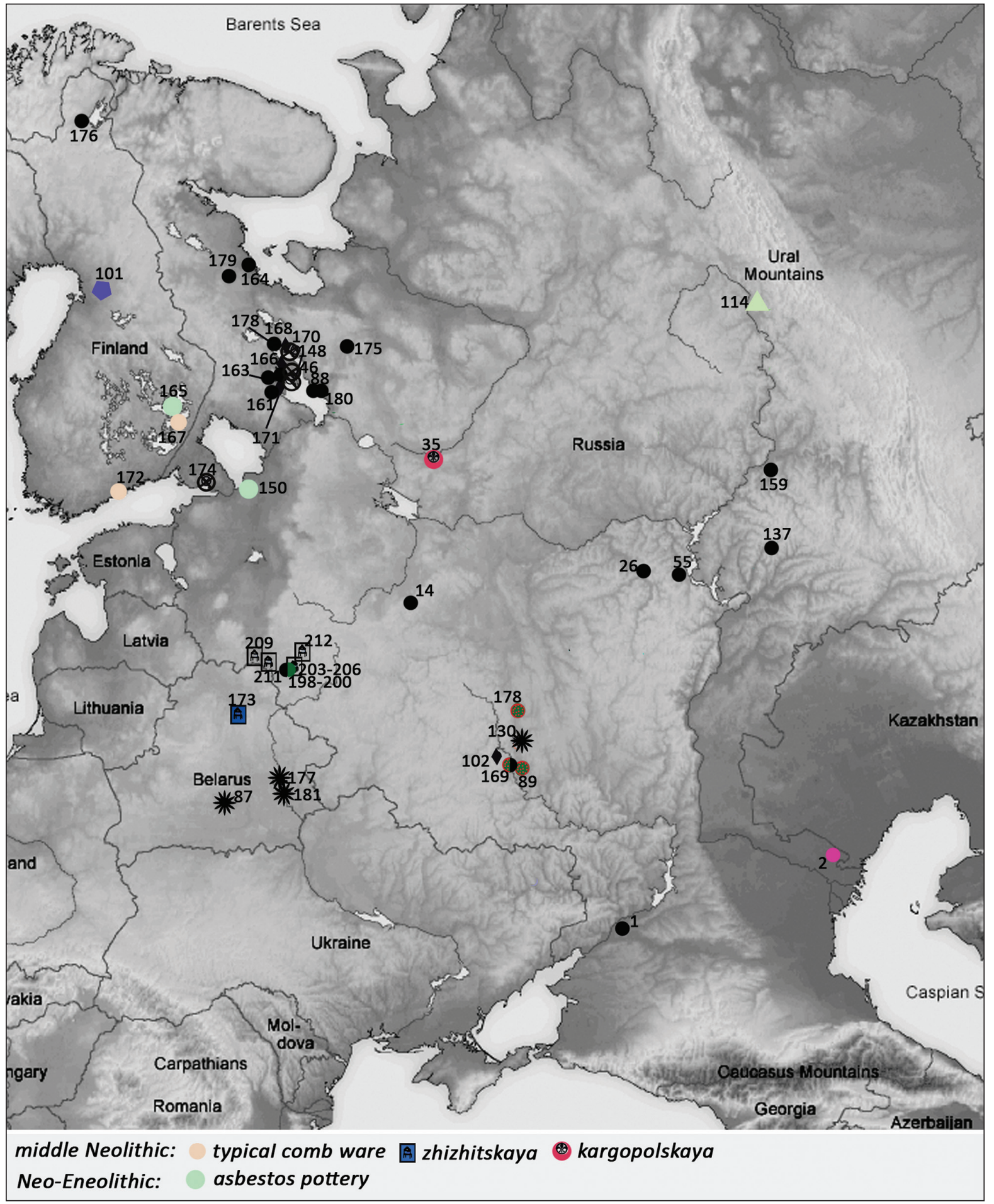

Map 4. Sites in the turn of the $5^{\text {th }}$ to $4^{\text {th }}$ millennium BC. 


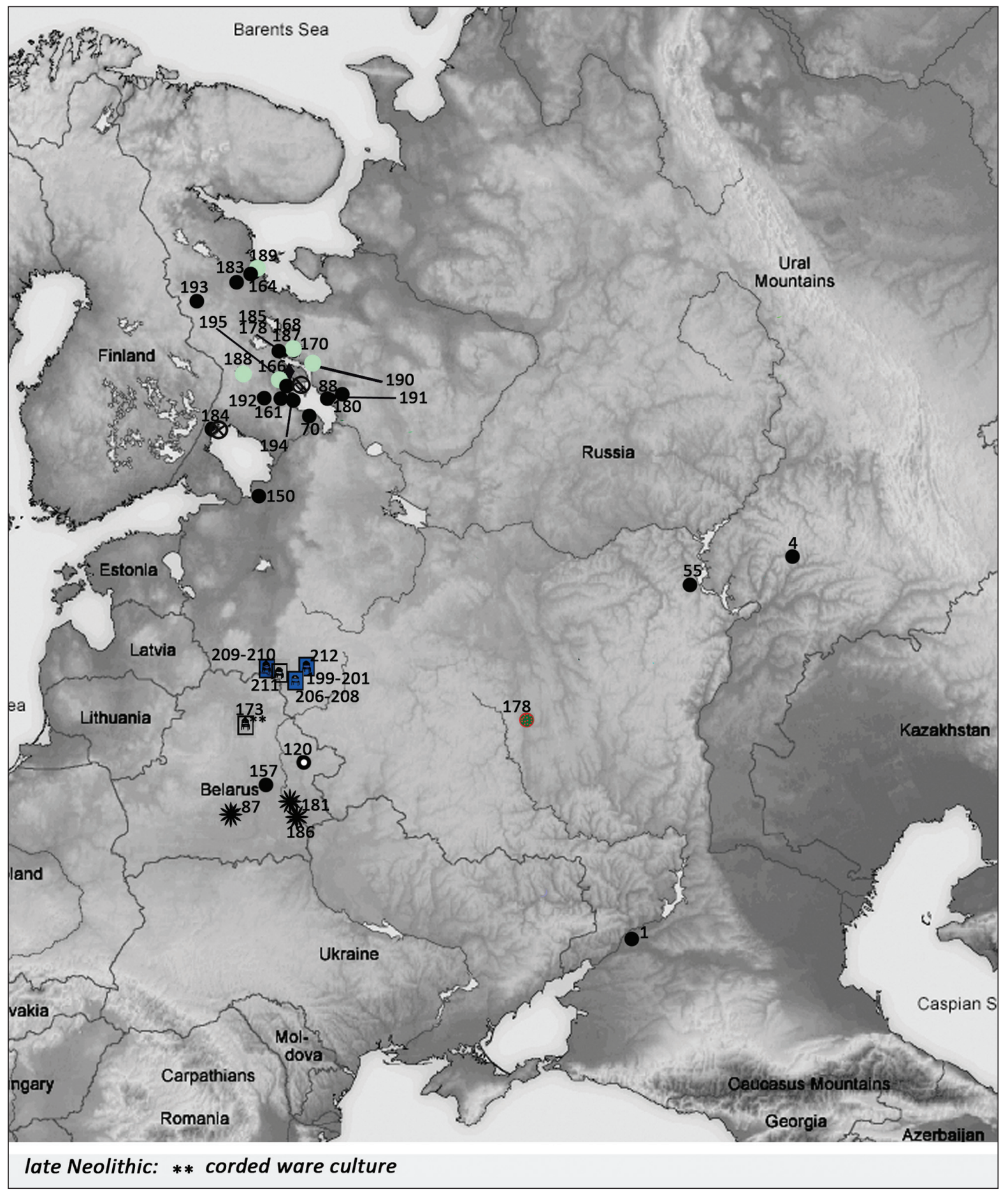

Map 5. Sites in the turn of the $4^{\text {th }}$ to $3^{\text {rd }}-2^{\text {nd }}$ millennium $B C$. 